\title{
Development of mouthwash with Rosmarinus officinalis extract
}

\author{
Isabela Moreira Baumgratz de Paula, ${ }^{1, *}$, Flávia Costa Moraes ${ }^{1}$, Orlando Vieira de Souza², \\ Célia Hitomi Yamamoto ${ }^{1}$
}

\author{
${ }^{1}$ Laboratory of Quality Control, Faculty of Pharmacy, Federal University of Juiz de Fora, ${ }^{2}$ Laboratory of Pharmacology of \\ Natural Products, Faculty of Pharmacy, Federal University of Juiz de Fora
}

\begin{abstract}
Rosmarinus officinalis, which belongs to the Lamiaceae family, is a species of medicinal flora with therapeutic properties. In order to exploit the benefits of these properties, a mouthwash formulation was developed, with careful selection of raw materials to meet pharmacotechnical requirements. Extracts of the plant were incorporated into a mouthwash, which was shown to have inhibitory action in vitro against the micro-organisms commonly found in periodontics. Controls for assessing the quality of the drugs were carried out, quantifying phenols and flavonoids as chemical markers. Mouthwash solutions were formulated containing $0.1,5$ and $10 \%$ ethanol extract of $R$. officinalis; and $0.05,5$ and $10 \%$ of the hexane fraction of $R$. officinalis. In order to evaluate synergism, ethanol extract and hexane fraction were also added to formulations containing $0.05 \%$ sodium fluoride and $0.12 \%$ chlorhexidine digluconate. These formulations were assessed for inhibitory effect against the specific microorganisms involved in the process of bacterial plaque formation, S. mutans (ATCC25175) and C. albicans(ATCC 10231), frequently found in cases of oral infections. The agar diffusion method was used to evaluate the inhibitory activity of extracts and formulations. All mouthwash solutions displayed inhibitory activity having higher sensitivity to $S$. mutans for the $5 \%$ ethanol extract $+0.05 \%$ sodium fluoride, and greater sensitivity to $C$. albicans for the $10 \%$ hexane fraction. Results were characterized by the appearance of a growth inhibition halo, justifying the utilization and association of extracts of $R$. officinalis.
\end{abstract}

Uniterms: Rosmarinus officinalis/pharmacognosy. Rosmarinus officinalis/Anti-microbial activity. Mouthwash. Periodontics/use of mouthwash. Medicinal plants.

Rosmarinus officinalis, pertencente à família Lamiaceae, é um exemplar da flora medicinal que possui propriedades terapêuticas. No intuito de usufruir destes benefícios, desenvolveu-se uma formulação de enxaguatório bucal com seleção criteriosa de matérias-primas que atendessem os requisitos farmacotécnicos. Incorporaram-se extratos dessa planta e verificou-se a capacidade inibitória in vitro frente a micro-organismos frequentemente encontrados em periodontias. Controles foram efetuados para a avaliação da qualidade dos fármacos, quantificando-se como marcadores químicos, os fenóis e os flavonóides. Formulações de enxaguatórios contendo $0,1,5$ e $10 \%$ de extrato etanólico de $R$. officinalis; e $0,05,5$ e $10 \%$ da fração hexânica de $R$. officinalis foram preparadas. Para avaliar o sinergismo, o extrato e a fração hexânica também foram adicionados às formulações que continham fluoreto de sódio $0,05 \%$ e diguclonato de clorexidina $0,12 \%$. Nessas formulações avaliou-se a capacidade inibitória frente a micro-organismos específicos do processo de formação de placa bacteriana, S. mutans (ATCC 25175) e C. albicans (ATCC 10231), frequentemente encontrada em quadros de infecções orais. Foi empregado o método de difusão em ágar para a avaliação da atividade inibitória dos extratos e das formulações. Todos os enxaguatórios demonstraram atividade inibitória, verificando-se maior sensibilidade a S. mutans, quando se utilizou extrato etanólico $5 \%$ + fluoreto de sódio $0,05 \%$ e sensibilidade maior a C. albicans, quando se utilizou fração hexânica a $10 \%$. Os resultados foram caracterizados pelo aparecimento de halo de inibição de crescimento, justificando a utilização e associação dos extratos de $R$. officinalis.

Unitermos: Rosmarinus officinalis/farmacognosia. Rosmarinus officinalis/atividade antimicrobiana. Enxaguatório bucal. Periodontia/uso de enxaguatório bucal. Planta medicinal.

\footnotetext{
*Correspondence: I. M. B. Paula. Laboratório de Controle de Qualidade, Faculdade de Farmácia, Universidade Federal de Juiz de Fora. Rua José Lourenço Kelmer, s/n, Campus Universitário, Bairro São Pedro, 36036-900 - Juiz de Fora - MG, Brasil. E-mail: isamoreiradepaula@hotmail.com
} 


\section{INTRODUCTION}

Rosmarinus officinalis belonging to the family Lamiaceae and popularly known as rosemary, has been widely used in folk medicine (Silva et al., 2008; Tressino, Gabriel, 2009). In the scientific community, it has demonstrated pharmacological action as a digestive, antispasmodic (Porte, Godoy, 2001), anti-inflammatory, anti-nociceptive (Takaki et al., 2008), anti-ulcer (Dias et al., 2000), hepatoprotective (Amim, Hamza, 2005), diuretic (Haloui et al., 2000) and antimicrobial (Newall, Anderson, Philipson, 2002; Silva et al., 2008), activities attributed to its various constituent phytochemicals (Sasaki et al., 2013).There are reports of the presence of neuroprotective activity for Alzheimer's (Liu et al., 2009; Lin et al., 2010; El Omri et al., 2010) and Parkinson's (Park et al., 2010) diseases, related to its major compounds including luteolin, carnosic acid and rosmarinic acid (Adams, Gmunder, Hamburguer, 2007).

Studies suggest potential of the antimicrobial effect of $R$. officinalis as a treatment for oral diseases (Bugno et al., 2006; Alvarenga et al., 2007; Bernardes et al., 2010; Maekawa et al., 2010). Considering that the use of herbal products appears to be economically viable, it represents an interesting alternative and contributes toward improving the population's access to solutions for the prevention and treatment of periodontal diseases. The aim of this study was to evaluate the antimicrobial activity of the extract and fractions of Rosmarinus officinalis, developing a mouthwash formulation with its extract, and to evaluate its synergism with substances currently used against dental biofilm.

\section{MATERIAL AND METHODS}

The leaves of Rosmarinus officinalis were collected from the Garden of Medicinal Plants of the Faculty of Pharmacy, at the Universidade Federal de Juiz de Fora. A voucher specimen was deposited in the Herbarium of the Botany Department of the Universidade Federal de Juiz de Fora (CESJ number 48253). The material was subjected to oven drying under forced ventilation for 48 hours at $37^{\circ} \mathrm{C}$ and triturated with an industrial blender. The pulverized material was subjected to extraction by static maceration in ethanol PA for 48 hours at room temperature. After removing solvent by rotary-evaporation on a RII-Buchi Rotavapor ${ }^{\circledR}$ device, part of the dry ethanol extract was suspended in a solution of water: ethanol (9:1) followed by liquid-liquid partition with organic solvents of increasing polarity: hexane, dichloromethane, ethyl acetate and butanol. The suspension formed was again subjected to the rotavapor to remove the solvents, producing fractions of $R$. officinalis extract.

The determination of total phenols present in samples of the ethanol extract and in its fractions was performed with the Folin-Ciocalteu method (Sousa et al., 2007), using gallic acid as the standard. The quantification of levels of flavonoids was performed by the spectrophotometric method (Vennat et al., 1992; Sobrinho et al., 2008). In the reaction for quantification, reagents used were glacial acetic acid, pyridine:ethanol solutionand aluminum chloride solution. Rutin was the standard substance used for building the calibration curve, where data were subjected to linear regression analysis by the method of least squares, and the equation of the line and correlation coefficient were calculated $(\rho)$.

For antimicrobial activity, minimum inhibitory concentration - MIC and minimum inhibitory concentration of adherence - MICA were determined using standard strains ofStreptococcus mutans ATCC 25175, lot 0307015 and Candida albicans ATCC 10231, lot 030640006, both provided by the Reference Laboratory of Microorganisms Oswaldo Cruz Foundation, Rio de Janeiro. The microbial suspension used was standardized at $10^{6} \mathrm{CFU} / \mathrm{mL}$ (colony forming units).

The culture media used for the determination of antimicrobial activity were: forS. mutans, TSA (Tryptic Soy Agar) with 24 hours of incubation and temperature of $34{ }^{\circ} \mathrm{C} \pm 2$, and forC. albicans, SDA (Sabouraud Dextrose Agar) with 48 hours of incubation at $25^{\circ} \mathrm{C} \pm 2$. For the evaluation of MIC,BHI (Brain Heart Infusion) was used for $S$. mutans and SDB (Brain Sabouraud Dextrose) for C. albicans, whereas for MIC A, BHI supplemented with $5 \%$ sucrose was used; all under the same conditions of incubation.

Determination of antimicrobial activity was performed by the diffusion agar method (USP, 2009). The culture medium was placed in sterilized Petri dishes $(20 \times 100 \mathrm{~mm})$ to form a base layer of $15.0 \mathrm{~mL}$. After solidification of the medium, $5.0 \mathrm{~mL}$ of agar containing $1 \%$ inoculum of the microorganism were distributed across the base layer. Subsequently, stainless steel cylinders with an $8 \mathrm{~mm}$ external diameter, $6 \mathrm{~mm}$ internal diameter and height of $10 \mathrm{~mm}$ were placed in the center of the plate to receive the samples. After the incubation period, the full diameter of the inhibition zone was measured with calipers, without deducting the diameter of the cylinder.

MIC was determined in microliter plates containing a liquid medium using the method proposed by the CLSI (2009). The sample concentrations ranged from 5.0 to $0.0025 \mathrm{mg} / \mathrm{mL}$, and chlorhexidine (5.0 to $0.039 \mu \mathrm{g} / \mathrm{mL}$ ) and miconazole nitrate $(5.0$ to $0,039 \mathrm{mg} / \mathrm{mL})$ were used as controls. 
The MICA of $S$. mutans for the surface was performed according to the methodology proposed by Freires et al., 2010. This test allows measurement of the lowest concentration of the sample able to inhibit the adherence of microorganism to glass, proving non-stick action of the extract in the presence of $S$. mutans. Sample concentrations were varied from $25 \mathrm{mg} / \mathrm{mL}$ to 3.12 to $\mathrm{mg} / \mathrm{mL}$, and chlorhexidine was used as the standard for concentrations from $100 \mu \mathrm{g} / \mathrm{mL}$ to $12.5 \mu \mathrm{g} / \mathrm{mL}$.

The mouthwash was prepared according to Table I.

After manipulation of the formulation, an agar diffusion test was performed to observe its activity. A comparison with a white (base) formulation, which exhibited antimicrobial activity due to its preservatives, was performed in order to evaluate increased activities of formulations containing extracts and active products. There was also synergism between extract and fluoride sodium $0.05 \%$ and $0.12 \%$ chlorhexidine gluconate.

Tests were performed in triplicate, and each plate had a single test solution.

\section{RESULTS AND DISCUSSION}

The total phenolic content ranged from 2.28 to
$21.13 \mathrm{~g} / 100 \mathrm{~g}$ in the extract and fractions of the Rosmarinus officinalis extract evaluated (Table II). Hexane fractions and ethyl acetate extracts showed higher total phenolic content when compared to the other products tested. Table II also shows that total flavonoid content ranged from 0.43 to $3.11 \mathrm{~g} / 100 \mathrm{~g}$ in both the extract and the fractions tested. The ethanol extract showed higher total flavonoids comparable to rutin. The variation of flavonoid levels in the fractions may be related to an increased amount of flavonoid non-glycosides, which are extracted in less polar solvents (Del Bano et al., 2004; Almeida et al., 2010).

The study of antimicrobial activity by the diffusion method showed that the ethanol extract and its fractions were effective in inhibiting the growth of $S$. mutans and C. albicans (Table III). This activity is attributed predominantly to the presence of phenolic constituents (Nascimento et al., 2000; Meléndez, Capriles, 2006).

Growth inhibition proved homogeneous, according to the degree of concentration of total phenols in samples of R. officinalis (Silva et al., 2008). These findings suggested the presence of bioactive compounds in the extract and fractions of rosemary with antimicrobial activity in vitro against Streptococcus mutans ATCC 25175 and Candida albicans ATCC 10231 strains.

TABLE I - Mouthwash formulation with ethanol extract of $R$. officinalis

\begin{tabular}{lccc}
\hline \multirow{2}{*}{ Components } & \multicolumn{3}{c}{ Mouthwash formulation } \\
\cline { 2 - 4 } & $\mathrm{A}$ & $\mathrm{B}$ & $\mathrm{C}$ \\
\hline Sodium benzoate & $0.1 \%$ & $0.1 \%$ & $0.1 \%$ \\
Saccharin & $0.1 \%$ & $0.1 \%$ & $0.1 \%$ \\
Propylene & $15 \%$ & $15 \%$ & $15 \%$ \\
Disodium EDTA & $0.05 \%$ & $0.05 \%$ & $0.05 \%$ \\
Mint Aroma & q.s.t. & q.s.t. & q.s.t. \\
Ethanol extract Rosmarinus officinalis & $0.1 \%$ & $0.1 \%$ & $0.1 \%$ \\
Sodium fluoride & ---- & $0.05 \%$ & --- \\
Chlorhexidine digluconate & ---- & --- & $0.12 \%$ \\
Water q.s.t. & q.s.t. $100 \mathrm{~mL}$ & q.s.t $100 \mathrm{~mL}$ & q.s.t $100 \mathrm{~mL}$ \\
\hline
\end{tabular}

TABLE II - Phenol and flavonoid content in extracts and fractions of Rosmarinus officinalis

\begin{tabular}{lcc}
\hline Samples & Total phenols $(\mathrm{g} / 100 \mathrm{~g}) \pm \mathrm{SD}$ & Total flavonoids $(\mathrm{g} / 100 \mathrm{~g}) \pm \mathrm{SD}$ \\
\hline Ethanol extract & $10.35 \pm 0.2^{*}$ & $3.11 \pm 0.1^{*}$ \\
Hexane fraction & $15.94 \pm 0.2^{*}$ & $0.77 \pm 0.03^{*}$ \\
Dichloromethane fraction & $7.45 \pm 0.1^{*}$ & $0.43 \pm 0.07^{*}$ \\
Fraction in ethyl acetate & $21.13 \pm 0.09^{*}$ & $2.55 \pm 0.06^{*}$ \\
Buthanol fraction & $2.28 \pm 0.03^{*}$ & $0.43 \pm 0.02^{*}$ \\
\hline
\end{tabular}

*Mean \pm Standard deviation of triplicate analysis. 
TABLE III - Results of extent of inhibition halos (mm), obtained from tests with Rosmarinus officinalis extracts; in concentrations of 5 to $10 \%$ tested against S. mutans ATCC 25175 and C. albicans ATCC 10231

\begin{tabular}{lcccc}
\hline \multirow{2}{*}{ Samples } & \multicolumn{4}{c}{ Extent of inhibition halos (mm) \pm SD } \\
\cline { 2 - 5 } & \multicolumn{3}{c}{$5 \%$} & \multicolumn{2}{c}{$10 \%$} \\
\cline { 2 - 5 } & S. mutans & C. albicans & S. mutans & C. albicans \\
\hline Ethanol extract & $25 \pm 0.2^{*}$ & $17 \pm 0.2^{*}$ & $28 \pm 0.1^{*}$ & $9.9 \pm 0.08^{*}$ \\
Hexane fraction & $29 \pm 0.06^{*}$ & $12 \pm 0.2^{*}$ & $29 \pm 0.1^{*}$ & $15 \pm 0.2^{*}$ \\
Dichloromethane fraction & $20 \pm 0.4^{*}$ & $9.3 \pm 0.1^{*}$ & $21 \pm 0.4^{*}$ & $9.5 \pm 0.4^{*}$ \\
Fraction in ethyl acetate & $20 \pm 0.3^{*}$ & $15 \pm 0.03^{*}$ & $20 \pm 0.2^{*}$ & $17 \pm 0.2^{*}$ \\
Buthanol fraction & $14 \pm 0.3^{*}$ & $16 \pm 0.1^{*}$ & $15 \pm 0.2^{*}$ & $10^{*}$ \\
Ampicillin $1.0 \mathrm{mg} / \mathrm{mL}$ & $30 \pm 0.1^{*}$ & -- & $30 \pm 0.1^{*}$ & --- \\
DMSO & Sh & $13 \pm 0.1^{*}$ & Sh & $13 \pm 0.1^{*}$ \\
Miconazole nitrate & & & & $18 \pm 0.1^{*}$ \\
$1.0 \mathrm{mg} / \mathrm{mL} 1.0 \mu \mathrm{g} / \mathrm{mL}$ & --- & $18 \pm 0.1^{*}$ & --- & \\
\hline
\end{tabular}

(---) Not applicable; (Sh) No inhibition halo.*Mean \pm Standard deviation of triplicate analysis.

Meléndez, Capriles (2006) tested the methanol extract of leaves of $R$. officinalis against 17 strains of Gram positive and Gram negative bacteria, reporting activityfor 10 strains and inhibition halos ranging from 12 to $18 \mathrm{~mm}$.

For the ethanol extract and $R$. officinalis fractions,a result for the Minimum Inhibitory Concentration was obtained. After following the incubation time method indicated in the Methods section, some concentrations exhibited growth while others did not, findings that concurred with the results of the agar diffusion test, where both exhibited activity against the strain $S$. mutans ATCC 25175 and C. albicans ATCC 10231 (Table IV).

The results were promising, since test values ranged from $0.312 \mathrm{mg} / \mathrm{mL}$ to $1.25 \mathrm{mg} / \mathrm{mL}$ for the $S$. mutans strain and from $1.25 \mathrm{mg} / \mathrm{mL}$ to $2.5 \mathrm{mg} / \mathrm{mL}$ for the C. albicans strain.

These results proved to be consistent with previous studies assessing the MIC of essential oil and methanol extract of Rosmarinus officinalis for bacterial strains and Candida albicans, which obtained values higher than $900 \mu \mathrm{g} / \mathrm{mL}$ and from 2.5 to $10 \mathrm{mg} / \mathrm{mL}$, respectively (Angioni et al., 2004; Celiktas, Bedir, Sukan, 2007).

Regarding the adherence test,defined as the lowest concentration of the extract able to inhibit the adherence of bacteria to glass after stirring, a MICA of $12.5 \mathrm{mg} / \mathrm{mL}$ was obtained for the ethanolic extract and $6.25 \mathrm{mg} / \mathrm{mL}$ for the fractions. The MICA for chlorhexidine was $25 \mu \mathrm{g} / \mathrm{mL}$, since adherence of bacteria to glass occurred at the concentration of $12.5 \mathrm{mg} / \mathrm{mL}$ (Figure 1). The results for the samples and dilutions of chlorhexidine are given in Table V.

Currently, some plants are being researched to fight infections that affect the oral cavity, mainly caused by the presence of bacterial biofilms (Alves et al., 2009; Soares et al., 2007; Freireset al., 2010; Silva et al., 2012). Takarada et al. (2010) reported that rosemary essential oil

TABLE IV - Test results for MIC of ethanol extract and fractions of Rosmarinus officinalis, chlorhexidine and miconazole nitrate

\begin{tabular}{lcc}
\hline Samples & Streptococcus mutans & Candida albicans \\
\hline Ethanol Extract & $0.625 \mathrm{mg} / \mathrm{mL}$ & $1.25 \mathrm{mg} / \mathrm{mL}$ \\
Hexane fraction & $0.312 \mathrm{mg} / \mathrm{mL}$ & $1.25 \mathrm{mg} / \mathrm{mL}$ \\
Dichloromethane fraction & $0.625 \mathrm{mg} / \mathrm{mL}$ & $2.5 \mathrm{mg} / \mathrm{mL}$ \\
Fraction in ethyl acetate & $0.625 \mathrm{mg} / \mathrm{mL}$ & $1.25 \mathrm{mg} / \mathrm{mL}$ \\
Buthanol fraction & $1.25 \mathrm{mg} / \mathrm{mL}$ & $1.25 \mathrm{mg} / \mathrm{mL}$ \\
Chlorhexidine & $12.5 \mu \mathrm{g} / \mathrm{mL}$ & --- \\
Miconazole nitrate & --- & $0.312 \mathrm{mg} / \mathrm{mL}$ \\
\hline
\end{tabular}

(---) Not applicable. 


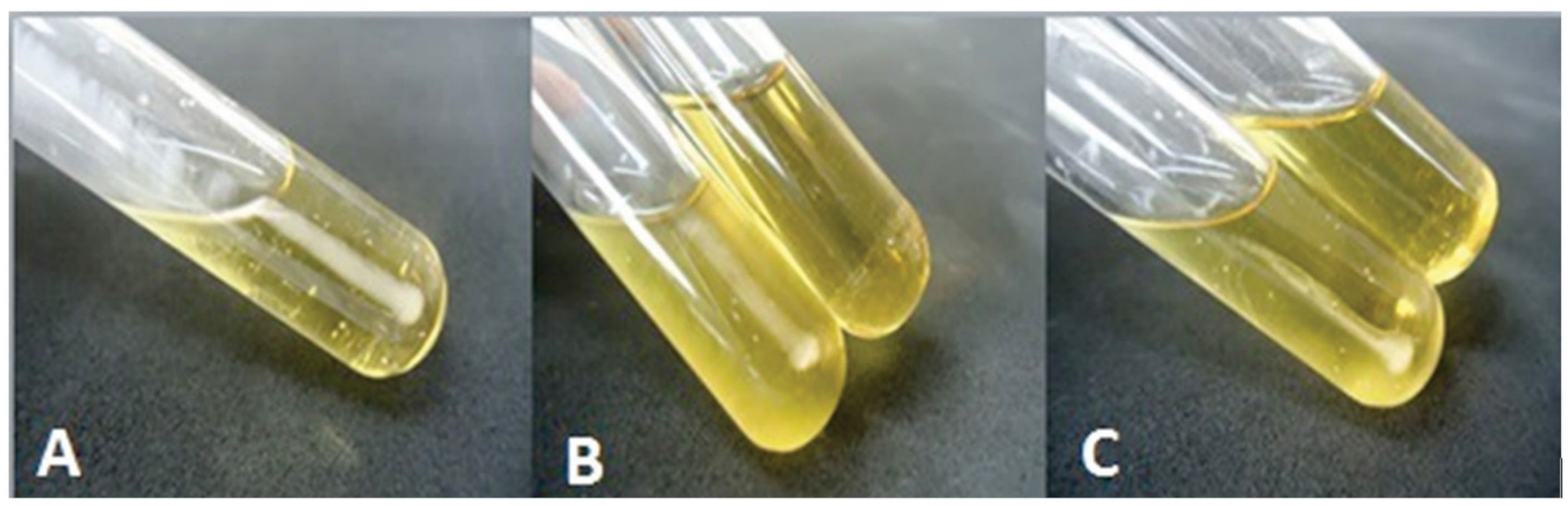

FIGURE 1 - MICA test against $S$. mutans ATCC 25175, positive control (A); fraction in Butanol of Rosmarinus officinalis in concentrations of $12.5 \mathrm{mg} / \mathrm{mL}$ and $6.25 \mathrm{mg} / \mathrm{mL}(\mathrm{B})$; and chlorhexidine in concentrations of $25 \mu \mathrm{g} / \mathrm{mL}$ and $12.5 \mu \mathrm{g} / \mathrm{mL}(\mathrm{C})$, respectively.

TABLE V - MICA results against $S$. mutans ATCC 25175 strain for ethanol extract and Rosmarinus officinalis fractions and chlorhexidine

\begin{tabular}{lc}
\hline Samples & MICA \\
\hline Ethanol Extract & $12.5 \mathrm{mg} / \mathrm{mL}$ \\
Hexane fraction & $6.25 \mathrm{mg} / \mathrm{mL}$ \\
Dichloromethane fraction & $6.25 \mathrm{mg} / \mathrm{mL}$ \\
Fraction in Ethyl Acetate & $6.25 \mathrm{mg} / \mathrm{mL}$ \\
Buthanol fraction & $6.25 \mathrm{mg} / \mathrm{mL}$ \\
Chlorhexidine & $25 \mu \mathrm{g} / \mathrm{mL}$ \\
\hline
\end{tabular}

showed inhibitory effect on the adherence of $S$. mutans and inhibitory activity against the growth of Gram-negative bacteria (A. actinommycete comitans, $P$. gengivalis and F. nucleatum).

Given these studies, we suggest that the search for alternative therapies represents the main goal of research into the properties of plant extracts. Furthering the search for new alternatives, Minimum Inhibitory Concentration was tested for mouthwash formulations with ethanol extract $(0.1 \%)$ and associations with sodium fluoride $0.05 \%$ and $0.12 \%$ chlorhexidine (Figure 2 ). The activity of the formulations was evaluated using the agar diffusion method and the results are shown in Table VI.

Nascimento et al. (2000) proposed the association between antibiotics and plant extracts for resistant bacteria, indicating the occurrence of synergism, allowing ineffective antibiotics to exert action against bacteria.

Cordeiro et al. (2006) developed a mouthwash formulation containing an association with hydroalcoholic extracts of Rosmarinus officinalis (Rosemary), Plantago major (Tanchagem), Tebebuia impetignosa (Purple Ipe),
TABLE VI - Results of extent of inhibition halos ( $\mathrm{mm}$ ), obtained in studiesof mouthwash with ethanol extract of Rosmarinus officinalis, in concentrations of $0.1,5$ and $10 \%$ tested against $S$. mutans ATCC 25175 and C. albicans ATCC 10231 by the agar diffusion method

\begin{tabular}{lcc}
\hline \multirow{2}{*}{ Mouthwash } & \multicolumn{2}{c}{ Extent of inhibition halos $(\mathrm{mm}) \pm \mathrm{SD}$} \\
\cline { 2 - 3 } & S. mutans & C. albicans \\
\hline $\mathrm{A}$ & $29 \pm 0.2^{*}$ & $15 \pm 0.1^{*}$ \\
$\mathrm{~B}$ & $30 \pm 0.4^{*}$ & $20 \pm 0.1^{*}$ \\
C & $29 \pm 0.5^{*}$ & $16 \pm 0.1^{*}$ \\
WHITE A & $20 \pm 0.3^{*}$ & $10 \pm 0.1^{*}$ \\
WHITE B & $27 \pm 0.5^{*}$ & $16 \pm 0.05^{*}$ \\
WHITE C & $28 \pm 0.4^{*}$ & $14 \pm 0.3^{*}$ \\
\hline
\end{tabular}

$*$ Mean \pm Standard deviation of triplicate analysis.

Achillea millefolium (Yarrow) and Nasturtium officinale (Watercress). The formulation (with and without vegetable extracts) was tested against the following strains: $S$. aureus, B. subtilis, P. aeruginosa, E. coli and E. fecalis. The mouthwash exhibited activity, but no significant difference was observed between the formulations containing plant extracts and those without.

De-Carli et al. (2010), in a double-blind randomized clinical trial, tested the synergism between the propolis ethanol extract of (Apis mellifera) at 5\% and Sodium Fluoride on the accumulation of dental biofilm. The association of propolis and fluoride enhanced the anticaries properties of fluorine through the chemical synergism, reducing biofilm formation and virulence of Streptococcus mutans, without changing the resident microflora.

The results of the present study corroborated those of the cited studies, having demonstrated antimicrobial, 


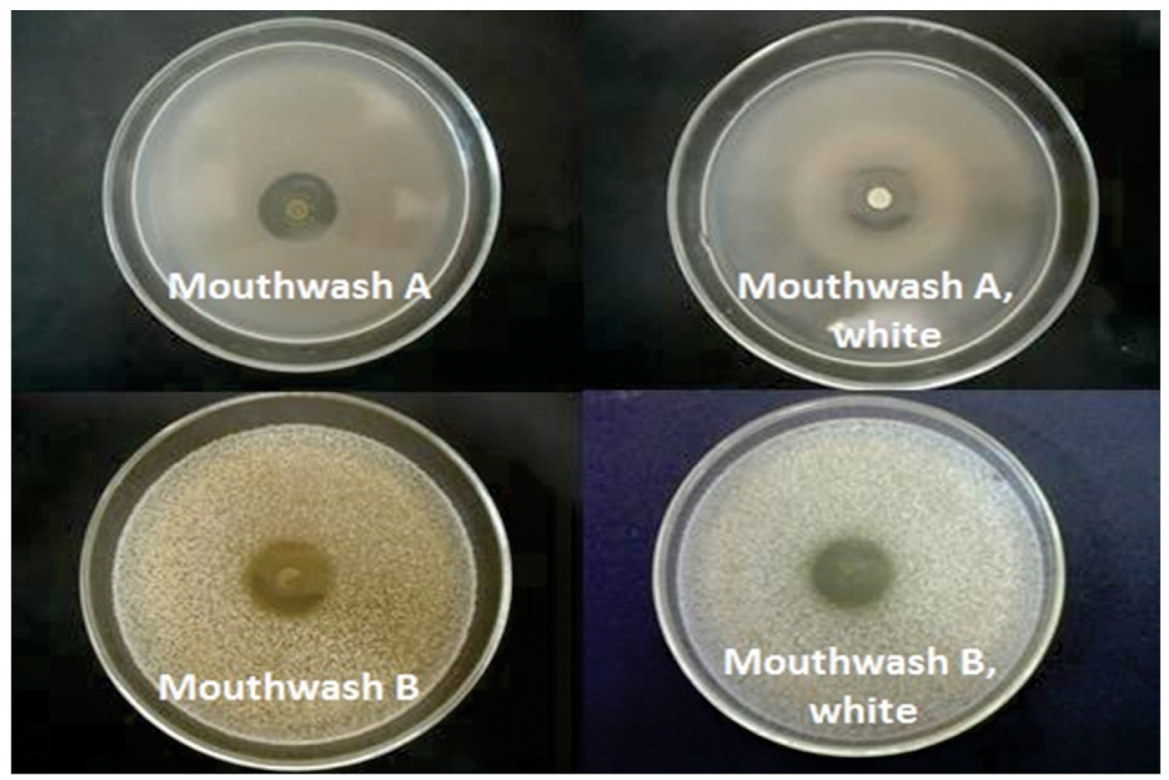

FIGURE 2 -Inhibition halos for mouthwash A and white; for mouthwash A to S. mutans. Inhibition halos for mouthwash B and white; for mouthwash B to C. albicans.

anti-adherent and synergetic activities for the extract and fractions of $R$. officinalis tested.

\section{CONCLUSION}

The results obtained by these methods allow us to conclude that the extract and fractions of $R$. officinalis exert activity against micro-organisms affecting the oral cavity and, when incorporated into the formulations of mouthwash, showed synergism with the substances currently used, indicating a promising product. However, further studies must be performed to enhance efficacy and safety.

\section{REFERENCES}

ADAMS, M.; GMUNDER, F.; HAMBURGUER, M. Plants traditionally used in age related brain disorders - a survey of ethnobotanical literature. J. Ethnopharmacol., v.113, n.3, p.363-381, 2007.

ALMEIDA, D.M.; CHAVES, L.L.; DEL-VECHIO-VIEIRA, G.; PINHO, J.J.R.G.; YAMAMOTO, C.H.; SOUSA, O.V. Teores de óleo essencial e flavonoides totais em amostras de Rosmarinus officinalis L. Rev. Bras. Farm., v.91, n.4, p.170-175, 2010.
ALVARENGA, A.L.; SCHWAN, R.F.; DIAS, D.R.; SCHWANESTRADA, K.R.F.; BRAVO-MARTINS, C.E.C. Atividade antimicrobiana de extratos vegetais sobre bactérias patogênicas humanas. Rev. Bras. Pl. Med., v.9, n.4, p.8691, 2007.

ALVES, P.M.; QUEIROZ, L.M.G.; PEREIRA, J.V.; PEREIRA, M.S.V.Atividade antimicrobiana, antiaderente e antifúngica in vitro de plantas medicinais brasileiras sobre microrganismos do biofilme dental e cepas do gênero Candida. Rev. Soc. Bras. Med. Trop., v.42, n.2, p.222-224, 2009.

AMIM, A.; HAMZA, A.A. Hepatoprotective effects of Hibiscus, Rosmarinus and Salvia on azathioprine-induced toxicity in rats. Life Sci., v.77, n.3, p.266-278, 2005.

ANGIONI, A.; BARRA, A.; CERETI, E.; BARILE, D.; COISSON, J.D.; ARLORIO, M.; DESSI, S.; CORONEO, V.; CABRAS, P. Chemical composition, plant genetic differences, antimicrobial and antifungal activity investigation of the essential oil of Rosmarinus officinalis L. J. Agric. Food Chem., v.52, n.11, p.3530-3532, 2004.

BERNARDES, W.A.; LUCARINI, R.; TOZATTI, M.G.; SOUZA, M.G.M.; SILVA, M.L.A.; FILHO, A.A.S.; MARTINS, C.H.G.; CROTTI, A.E.M.; PAULETTI, P.M.; GROPPO, M.; CUNHA, W.R. Antimicrobial activity of Rosmarinus officinalis against oral pathogens: relevance of carnosic acid and carnosol. Chem. Biodivers., v.7, n.7, p.1835-1840, 2010. 
BUGNO, A.; BUZZO, A.A.; NAKAMURA, C.T.; PEREIRA, T.C.; MATOS, D.; PINTO, T.J.A.. Avaliação da contaminação microbiana em drogas vegetais. Rev. Bras. Ciên. Farm., v.41, n.1, p.491-497, 2006.

CELIKTAS, O.Y., BEDIR, E.; SUKAN, F.V. Antimicrobial activities of methanol extracts and essential oils of Rosmarinus officinalis, depending on location and seasonal variations. Food Chem., v.101, n.4, p.1457, 2007.

CLINICALAND LABORATORY STANDARDS INSTITUTE (CLSI). Methods for dilution antimicrobial susceptibility tests for bacteria that grow aerobically. Approved standard8ed., M07-A8. Wayne: CLSI, PA. 2009.

CORDEIRO, C.H.G.; SACRAMENTO, L.V.S.; CORREA, M.A.; PIZZOLitTO, A.C.; BAUAB, T.M. Análise farmacognóstica e atividade antibacteriana de extratos vegetais empregados em formulação para a higiene bucal. Rev. Bras. Ciênc. Farm., v.42, n.3, p.395-404, 2006.

DE-CARLI, A.D.; ZÁRATE-PEREIRA, P.; DE-CARLI, G.; ZAFALON, E.; ZÁRETE, C.B.R.; YASSUMOTO, L.M. Ação da própolis de Apis melífera associada ao fluoreto de sódio sobre o biofilme dental: ensaio clínico duplo cego randomizado. Rev. Odontol. Bras-Central, v.19,n.1, p.310$313,2010$.

DEL-BANO, M.J.; LORENTE, J.; CASTILLO, J.; GARCIA, O.B.; DEL RIO, J.A.; MARIM, M.P.; ORTUNO, A.; IBARRA, I. Flavonoid distribuition during the development of leaves, flowers, stems, and roots Rosmarinus officinalis. Postulation of a biosynthetic pathway. J. Agric. Food Chem., v.52, n.16, p.4987-4992, 2004.

DIAS, P.C.; FOGLIO, M.A.; POSSENTI, A.; DE CARVALHO, J.E. Antiulcerogenic activity of crude hydroalcoholic extracts of Rosmarinus officinalis L. J. Ethnopharmacol.,v.69, n.1, p.57-62, 2000.

EL OMRI, A.; HAN, J.; YAMADA, P.; KAWADA, K.; ABDRABBAH, M.B.; ISODA, H. Rosmarinus officinalis polyphenols activate cholinergic activities in PC12 cells through phosphorylation of ERK1/2. J. Ethnopharmacol., v.131, n.2, p.451-458, 2010.
FREIRES, I.A.; ALVES, L.A.; JOVITO, V.C.; ALMEIDA, L.F.D.; CASTRO, R.D.; PADILHA, W.W.N. Atividades antibacteriana e antiaderente in vitro de tinturas de Schinus terebinthinfolius (Aroeira) e Solidago microglossa (Arnica) frente a bactérias formadoras do biofilme dentário. Odontol. Clín.-Cient., v.9, n.2, p.139-143, 2014.

HALOUI, M.; LOUEDEC, L.; MICHEL, J.B.; LYOUSSI, B. Experimental diuretic effects of Rosmarinus officinalis and Centaurium erythraea. J. Ethnopharmacol., v.71, n.3, p.465-472, 2000.

LIN, C.W.; WU, M.J.; LIU, .IY.; SU, J.D.; YEN, J.H. Neurotrophic and cytoprotective action of luteolin in PC12 cells through ERK-dependent induction of Nrf2-driven HO-1 expression. J. Agric. Food Chem., v.58, n.7, p.44774486, 2010.

LIU, R.; GAO, M.; QIANG, G.F.; ZHANG, T.T.; LAN, X.; YING, J.; DU, G.H. The anti-amnesic effect of luteolin against amyloid b25-35 peptide induced toxicity in mice involve the protection of the neurovascular unit. Neuroscience, v.162, n.4, p.1232-1243, 2009.

MAEKAWA, L.E.; BRIGHENTI, F.L.; LAMPING, R.; OLIVEIRA, L.D.; MARCACCI, S.; KOGA-ITO, C.Y. Atividade antimicrobiana de enxaguatórios bucaissemálcool à base de clorexidina sobre Candida albicans. Rev. Odontol. UNESP, v.39, n.1, p.15-19, 2010.

MELÉNDEZ, P.A.; CAPRILES, V.A. Antibacterial properties of tropical plants from Puerto Rico. Phytomedicine, v.13, n.4, p.272-276, 2006.

NASCIMENTO, G.G.F.; LOCATELLI, J.; FREITAS, P.C.; SILVA, G.L. Antibacterial activity of plant extracts and phytochemicals on antibiotic-resistant bacteria. Braz. J. Microbiol., v.31, p.247-256, 2000.

NEWALL, C.A.; ANDERSON, L.A.; PHILIPSON, J.D. Plantas medicinais: guia para profissional de saúde. São Paulo: Premier, 2002. 308 p.

PARK, S.E.; KIM, S.; SAPKOTA, K.; KIM, S.J. Neuroprotective effect of Rosmarinus officinalis extract on human dopaminergic cell line, SH-SY5Y. Cell. Mol. Neurobiol., v.30, n.5, p.759-767, 2010 . 
PORTE, A.; GODOY, R.L.O. Alecrim (Rosmarinus officinalis L.): propriedades antimicrobiana e química do óleo essencial. B. do CEPPA, v.19, n.2, p.193-210, 2001.

SASAKI, K.; EL OMRI, A.; KONDO, S.; HAN, J.; ISODA, H. Rosmarinus officinalis polyphenols produce anti-depressant like effect through monoaminergic and cholinergic functions modulation. Behav. Brain Res., v.238, n.1, p.8694, 2013.

SILVA, I.C.G.; BEZERRA, L.M.D.; FERREIRA, G.L.S.; CASTRO, R.D. Atividade antifúngica do eugenol associado a antifúngicos sintéticos sobre espécies de Candida albicans. Rev-ICO, v.10, n.2, p.21, 2012.

SILVA, M.S.A.; SILVA, M.A.R.; HIGINO, J.S.; PEREIRA, M.S.V.; CARVALHO, A.A.T. Atividade antimicrobiana e antiaderente in vitro do extrato de Rosmarinus officinalis Linn. sobre bactérias orais planctônicas. Rev. Bras. Farmacogn., v.18, n.2, p.236-240, 2008.

SOARES, D.G.S.; OLIVEIRA, C.B.; LEAL, C.; DRUMOND, M.R.S.; PADILHA, W.W.N. Atividade antibacteriana in vitro da tintura de aroeira (Schinus terebinthifolius) na descontaminação de escovas dentais contaminadas pelo S. mutans. Pesq. Bras. Odontoped. Clin. Integr., v.7, n.3, p.253-257, 2007.

SOBRINHO, T.J.S.P.; SILVA, C.H.T.P.; NASCIMENTO, J.E.; MONTEIRO, J.M.; ALBUUQUERQUE, U.P.; AMORIM, E.L.C. Validação de metodologia espectrofotométrica para quantificação dos flavonóides de Bauhinia cheilantha (Bongard) Steudel. Rev. Bras. Ciênc. Farm., v.44, n.4, p.683-689, 2008.
SOUSA, C.M.M.; SILVA, H.R.; VIEIRA-JUNIOR, G.M.; AYRES, M.C.C.; COSTA, L.S.; ARAÚJO, D.S.; CAVALCANTE, L.C.; BARROS, E.D.S.; ARAÚJO, P.B.M.; BRANDÃO, M.S.; CHAVES, M.H. Fenóis totais e atividade antioxidante de cinco plantas medicinais. Quím. Nova, v.30, n.2, p.351-355, 2007.

TAKAKI, I.; BERSANI, A.L.E.; VENDRUSCOLO, A.; SARTORETTO, S.M.; DINIZ, S.P.; BERSANI-AMADO, C.A. Anti-inflammatory and antinociceptive effects of Rosmarinus officinalis L. essential oil in experimental animal models. J. Med. Food, v.11, n.4, p.741-746, 2008.

TAKARADA, K.; KIMIZUKA, R.; TAKAHASHI, N.; HONMA, K.; OKUDA, K.; KATO, T. A comparison of the antibacterial efficacies of essential oils against oral pathogens. Oral Microbiol. Immunol., v.19, n.1, p.61-64, 2010.

TRESSINO, E.S.; GABRIEL, K.C. Estudo das aplicações farmacológicas do óleo essencial de alecrim (Rosmarinus officinalis). Infarma, v.21, n.3/4, p.44-48, 2009.

VENNAT, B.; GROSS, D.; POURRAT, H. Hamamelis virginiana: identification and assay of proanthocyanidins, phenolic acids and flavonoids in leaf extracts. Pharm. Acta Helvetiae, v.67, n.1, p.11-14, 1992.

Received for publication on $24^{\text {th }}$ September 2013 Accepted for publication on $03^{\text {rd }}$ April 2014 